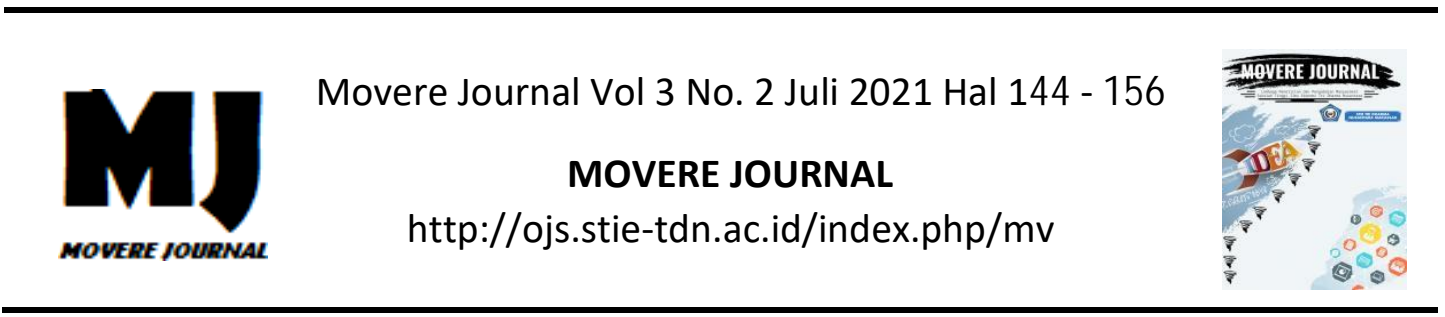

\title{
Pengaruh Mutu Tabungan Dan Promosi Penjualan Terhadap Minat Menabung Nasabah Pada PT. Bank Sulselbar Makassar
}

\author{
Moh. Ali Wairooy \\ Politeknik LP3i Makassar \\ Email : mohaliwairooy@gmail.com
}

\begin{abstract}
Abstrak: Penelitian ini bertujuan Untuk menguji dan menganalisis pengaruh Mutu Tabungan terhadap Minat Menabung Nasabah Pada PT. Bank SULSELBAR Makassar. Untuk menguji dan menganalisis pengaruh Promosi Penjualan terhadap Minat Menabung Nasabah Pada PT. Bank SULSELBAR Makassar, dan Untuk menguji dan menganalisis pengaruh Mutu Tabungan dan Promosi Penjualan secara simultan terhadap Minat Menabung Nasabah Pada PT. Bank SULSELBAR Makassar. Pengumpulan data menggunakan data primer yang diperoleh dari kuesioner dengan populasi sebanyak 165.957 nasabah serta sampel menggunakan rumus Slovin diperoleh sebanyak 100 responden. Hasil kuesioner tersebut telah diuji validitas dan realibiltasnya, juga diuji asumsi klasik berupa asumsi Normalitas dan asumsi Heteroskedastisitas. Metode analisis data menggunakan teknik regresi berganda. Berdasarkan analisis secara parsial (uji-t) dan secara simultan (Uji-f) ternyata hasil penelitian membuktikan bahwa semua hipotesis diterima dikarenakan Mutu Tabungan dan Promosi Penjualan berpengaruh positif dan signifikan secara parsial maupun simultan terhadap Minat Menabung pada PT. Bank SULSELBAR Makassar.
\end{abstract}

Kata Kunci: Mutu Tabungan, Promosi Penjualan, Minat Menabung

Abstract: This study aims to examine and analyze the effect of the Quality of Savings on the Saving Interest of Customers at PT. Bank SULSELBAR Makassar. To examine and analyze the effect of Sales Promotion on Customer Saving Interests at PT. Bank SULSELBAR Makassar. The second, to examine and to analyze the effect of Savings Quality and Sales Promotion simultaneously on the Savings Interest of Customers at PT. Bank SULSELBAR Makassar. Collecting data using primary data obtained from questionnaires with the population 165,957 customers and samples using the Slovin formula obtained as many as 100 respondents. The results of the questionnaire have been tested for validity and reliability. It also tested by classical assumptions in the form of Normality assumptions and Heteroscedasticity assumptions. Methods of data analysis use mmultiple regression techniques. Based on the partial analysis ( $t$-test) and simultaneously ( $f$-test) the results of the research prove that all hypotheses are accepted because the Quality of Savings and Sales Promotion have a positive and significant effect either partially or simultaneously on Saving Interests at PT. Bank SULSELBAR Makassar.

Keywords : Quality of Savings, Sales Promotion, Saving Interest 


\section{A. PENDAhuluan}

Perkembangan dunia bisnis saat ini sangat pesat, membuat para pelaku bisnis harus saling bersaing untuk menarik para pelanggan. Masyarakat kini mulai berpikir selektif dan smart dalam memilih suatu produk, sehingga mereka akan mendapatkan kegunaan atau manfaat yang mereka cari dari sebuah produk (Mawardi, 2018). Untuk mempertahankan kelangsungan hidup dalam sistem keuangan yang turbulen, sebuah bank harus dapat berkompetisi dengan bank-bank kompetitor dan financial intermediary unit lainnya yang juga memberikan layanan jasa keuangan. Suatu bank dikatakan berhasil memenangkan kompetisi bisnisnya jika ia mampu memberikan jasa layanan keuangan bank lebih baik daripada kompetitornya, sekaligus mampu mengadaptasikan diri dengan setiap perubahan lingkungan. Dengan kemampuan manajerial yang dimiliki, bagaimana para manajer bank dapat mengubah ancaman lingkungan yang turbulen menjadi berbagai peluang usaha yang menguntungkan.

Berdasarkan penelitian terdahulu, menurut penelitian yang dilakukan oleh Syaribulan (2018) membuktikan bahwa adanya pengaruh dari produk (mutu) tabungan dan promosi penjualan berpengaruh terhadap minat menabung nasabah. Hasil penelitian tersebut, berbeda dengan penelitian yang dilakukan oleh Mawardi (2018) yang membuktikan bahwa Promosi penjualan tidak berpengaruh terhadap minat menabung serta selanjutnya menurut Rezeki dan Sukmadilaga (2018) yang membuktikan bahwa kualitas (mutu) produk tabungan tidak berpengaruh positif terhadap minat nasabah menabung. Berdasarkan hasil penilitian tersebut, adanya Gap yang menjelaskan perbedaan hasil penelitian sehingga diperlukan penelitian lebih lanjut mengenai Mutu Tabungan dan Promosi Penjualan terhadap Minat Menabung.

Hubungan Mutu Tabungan terhadap Minat Menabung menurut Suryani (2017) menyatakan bahwa pemahaman terhadap produk dan jasa perbankan serta karakteristiknya sangat penting bagi pemasar agar dapat menawarkan produk tersebut secara tepat. Produk adalah pemahaman subyektif produsen atas sesuatu yang bisa ditawarkan sebagai usaha untuk mencapai tujuan organisasai melalui pemenuhan kebutuhan dan keinginann konsumen, sesuai dengan kompetensi dan kapasitas organisasi serta daya beli pasar, selain itu produk dapat pula di definisikan sebagai persepsi konsumen yang di jabarkan oleh produsen melalui hasil produksi atau operasinya. Apabila produsen dapat menjelasankan mutu produk kepada konsumen dengan didukung berbagai keunggulan produk tersebut, maka dapat meningkatkan minat menabung nasabah sehingga hal tersebut dapat menjadi penanda bahwa nasabah telah menikmati keunggulan dari produk tersebut.

Hubungan Promosi Penjualan terhadap Minat Menabung menurut Daniel dan Anas (2017:89) menyatakan bahwa Promosi merupakan salah satu cara bank untuk menarik dan mempertahankan masyarakat 
agar tetap menabung pada bank tersebut Namun kegiatan promosi yang dilakukan bank juga bisa mengurangi minat masyarakat untuk menabung pada bank tersebut apabila dilakukan dengan tujuan dan penyampaian yang tidak tepat bahkan berlebihan. Oleh karena itu, bank harus dapat memanfaatkan dengan baik dan benar media promosi seperti iklan pada media cetak atau elektronik, promosi langsung dan lain sebagainya. Dalam hal ini bank harus mengetahui media promosi yang paling mudah dimengerti dan sering dijumpai oleh masyarakat.

Fenomena ini dikaji berdasarkan penjelasan Direktur Pemasaran Bank Sulselbar Rosmala Arifin yang mengatakan bahwa hingga Mei 2020, pencapaian target kredit telah mencapai 99,04 persen dari target kredit kuartal II/2020. Sementara target himpunan dana pihak ketiga pada kuartal II/2020 telah tercapai 90 persen. Pada masa pandemi Covid-19 ini perkembangan Bank Sulselbar lebih berdampak pada kemampuan profitabilitas perseroan. Hal ini dikarenakan penundaan pembayaran atau angsuran debitur yang terdampak Covid-19 sehingga membuat margin bank menjadi tertekan (finansial.bisnis.com, 2020).

Alasan penelitian ini dilakukan pada dikarenakan diawal Tahun 2020 Bank Pembangunan Daerah (BPD) Sulsel bakal berhasil. Menyabet penghargaan dari Marketing Research Indonesia (MRI) bekerja sama dengan Infobank. Prestasi membanggakan tersebut diraih saat Bank Sulsel bakal dipimpin seorang Wanita cantik yang ditunjuk pemegang saham Bank Sulselbar sebagai PLT Dirum Prestasi Bank
Sulselbar meraih juara di kelompok Bank BPD dari hasil survei "Satisfaction, Loyalty, and Engagement (SLE) 2020. Bank Sulselbar sejak awal tahun 2019 telah menerapkan sistem pelayanan terpadu dengan mendorong internalisasi budaya kerja yang disingkat prioritas prima yaitu profesional, inovasi, kerjasama, integritas dan layanan prima (trotoar.id, 2020).paragraf atau 2 halaman. Afriyani (2016:6). Bagian ini juga mencakup beberapa literatur yang menjadi landasan teoritis studi dan mencakup studi atau penelitian sebelumnya. Zulkifli (2015:12).

\section{B. TELAAH LITERATUR DAN PENGEMBANGAN HIPOTESIS}

\section{Perbankan}

Bank adalah sebuah lembaga intermediasi keuangan umumnya didirikan dengan kewenangan untuk menerima simpanan uang, meminjamkan uang, dan menerbitkan promes atau yang dikenal sebagai banknote. Kata bank berasal dari bahasa Italia banca berarti tempat penukaran uang. Secara garis besar hal-hal yang bersifat makro dari bank umum. Maka Latumaerissa, (2011:135) memberikan beberapa definisi tentang Bank Umum (commercial bank) sebagai:

a. Suatu badan usaha yang kegiatan utamanya menerima simpanan dari masyarakat dan/atau pihak lainnya, kemudian mengalokasikannya kembali untuk memperoleh keuntungan serta menyediakan jasa-jasa dalam lalu lintas pembayaran.

b. Badan usaha yang menghimpun 
dana dari masyarakat dalam bentuk simpanan dan mengeluarkanya kepada masyarakat dalam rangka meningkatkan taraf hidup rakyat banyak (UU No.7/1992).

\section{Minat Menabung}

Minat menabung adalah keinginan yang datang dari diri sendiri untuk melakukan penyimpanan atas uang mereka di bank dengan tujuan tertentu. Berdasarkan penjelasan tersebut, maka dapat disimpulkan minat menabung adalah minat yang diasumsikan sebagai minat beli yang merupakan perilaku yang muncul sebagai respon terhadap objek yang menunjukkan keinginan pelanggan untuk melakukan pembelian dalam hal menabung pada bank yang telah sesuai dengan keinginan nasabah.

\section{Mutu Tabungan}

Berdasarkan penjelasan tersebut, maka mutu tabungan adalah keunggulan pada simpanan yang bertujuan untuk mempermudah nasabah dalam melakukan transaksi dengan syarat - syarat yang telah disepakati.

Menyediakan produk yang berkualitas sangat penting bagi bank, karena semakin baik kualitas produk yang ditawarkan oleh bank, semakin puas nasabah dalam menggunakan produk tersebut. Sehingga semakin tinggi pula Minat Menabung untuk melakukan kegiatan menabung kembali.

\section{Promosi Penjualan}

Menurut Tjiptono (2014: 219) Promosi dapat didefinisikan sebagai suatu bentuk komunikasi pemasaran, komunikasi pemasaran adalah aktivutas pemasaran yang berusaha menyebarkan informasi, mempengaruhi, membujuk maupun mengingatkan pasar sasaran atas perusahaan dan produknya agar bersedia menerima, membeli, dan loyal pada produk yang ditawarkan perusahaan yang bersangkutan.

Berdasarkan beberapa pendapat para ahli tersebut dapat diketahui bahwa Promotion Mix merupakan penyampaian informasi dari penjual kepada pembeli untuk mempengaruhi sikap dan tingkah laku dalam rangka menciptakan pertukaran, sehingga tujuan untuk meningkatkan kuantitas penjualan diharapkan dapat terealisasi.

\section{Gambar 1. Kerangka Konseptual}

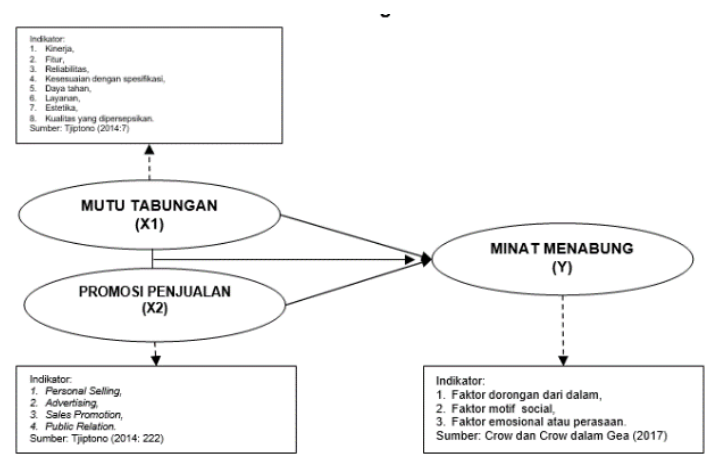

\section{METODE PENELITIAN}

Jenis penelitian ini merupakan penelitian dengan menggunakan pendekatan kuantitatif.

Penelitian ini mengambil data pada PT. Bank SULSELBAR Makassar yang beralamat di Jl. Dr Sam Ratulangi No.16 Makassar. Penelitian ini dilakukan pada 
bulan Oktober sampai Desember 2020.

Sesuai dari observasi yang dilakukan pada PT. Bank Sulselbar Makassar maka populasi dalam penelitian ini meliputi seluruh jumlah nasabah tahun 2019 di PT. Bank Sulselbar Makassar yang berjumlah 165.957 nasabah.

Sugiyono (2017: 115) menyatakan bahwa sampel adalah bagian dari jumlah dan karakteristik yang dimiliki oleh populasi tersebut. Jumlah anggota sampel sering dinyatakan dalam ukuran sampel. Rumus yang digunakan rumusan Slovin, yaitu:

$$
n=\frac{\mathrm{N}}{1+\mathrm{N}(\mathrm{e})^{2}}
$$

Keterangan:

$\mathrm{n}=$ Ukuran Sampel

$\mathrm{N}=$ Ukuran Populasi

$\mathrm{e}=$ Persentase kelonggaran ketidaktelitian karena kesalahan pengambilan sampel yang masih dapat ditolerir atau diinginkan. Dalam penelitian ini persentase tersebut adalah $10 \%$.

$$
n=\frac{165.957}{1+165.957(0,1)^{2}}
$$

$\mathrm{n}=99,94$ (dibulatkan menjadi 100)

$\begin{array}{rrr}\text { Teknik } & \text { pengambilan } & \text { sampel } \\ \text { yang di } & \text { lakukan adalah }\end{array}$ menggunakan metode sampel acak sederhana (metode simple random sampling) kepada nasabah di PT. Bank Sulselbar Makassar.

Teknik pengumpulan data dalam penelitian ini adalah : kuisioner dan observasi.
Metode analisis yang digunakan adalah Analisis deskriptif.

Keseluruhan pengolahan data dilakukan dengan menggunakan bantuan program SPSS (Statistik Product and Standart Solution) Versi 23.

\section{HASIL DAN PEMBAHASAN}

\section{Hasil Penelitian}

Karakteristik responden yang diamati dalam penelitian ini meliputi jenis kelamin dan umur. Deskripsi karakteristik responden disajikan sebagai berikut:

\section{a. Identitas Responden Menurut Jenis Kelamin}

Tabel 1 Identitas Responden Menurut Jenis Kelamin

\begin{tabular}{|c|c|c|}
\hline $\begin{array}{c}\text { Jenis } \\
\text { kelamin }\end{array}$ & $\begin{array}{c}\text { Jumlah } \\
\text { (Orang) }\end{array}$ & $\begin{array}{c}\text { \% } \\
\text { (Persen) }\end{array}$ \\
\hline Laki- laki & 33 & 33 \\
\hline Perempuan & 67 & 63 \\
\hline Total & 100 & 100 \\
\hline
\end{tabular}

Sumber : Data olahan SPSS (2020)

Tabel 1 menunjukkan bahwa responden dengan jenis kelamin laki-laki sebanyak 33 orang (33\%) dan responden dengan jenis kelamin perempuan sebanyak 67 orang (67\%). Berdasarkan penjelasan tersebut, maka responden yang mengisi kuesioner ada rata - rata yang berjenis kelamin Perempuan.

\section{b. Identitas responden menurut umur}

Tabel 2 Identitas Responden Menurut Umur

\begin{tabular}{|l|l|l|}
\hline Usia & $\begin{array}{l}\text { Jumlah } \\
\text { (Orang) }\end{array}$ & $\begin{array}{l}\% \\
\text { (Persen) }\end{array}$ \\
\hline$<25$ Tahun & 42 & 42 \\
\hline
\end{tabular}




\begin{tabular}{|l|l|l|}
$26-30$ Tahun & 39 & 39 \\
\hline $31-35$ Tahun & 11 & 11 \\
\hline$>36$ Tahun & 8 & 8 \\
\hline Total & 100 & 100 \\
\hline
\end{tabular}

Sumber : Data olahan SPSS (2020)

Tabel 2 menunjukkan bahwa responden dengan umur dibawah 25 tahun sebanyak 42 orang (42\%), umur 26 - 30 tahun sebanyak 39 orang (39\%), umur 31 - 35 tahun sebanyak 11 orang (11\%), dan umur diatas 36 tahun sebanyak 8 orang $(8 \%)$. Berdasarkan penjelasan tersebut, maka responden yang mengisi kuesioner ada rata - rata yang dibawah berumur 25 tahun.

\section{Pembahasan}

Analisis regresi linear berganda digunakan dalam penelitian ini dengan tujuan untuk mengetahui ada tidaknya pengaruh variabel bebas terhadap variabel terikat. Perhitungan statistik dalam analisis regresi linear berganda yang digunakan dalam penelitian ini adalah dengan menggunakan bantuan program komputer SPSS for Windows versi 23.0. Ringkasan hasil pengolahan data dengan menggunakan program SPSS tersebut adalah sebagai berikut:

\section{Tabel 3 Hasil Uji Analisis Regresi Linier Berganda}

\begin{tabular}{|c|c|c|c|}
\hline \multirow[b]{2}{*}{ Model } & \multicolumn{2}{|c|}{$\begin{array}{l}\text { Unstandardized } \\
\text { Coefficients }\end{array}$} & $\begin{array}{l}\text { Standardized } \\
\text { Coefficients }\end{array}$ \\
\hline & B & Std. Error & Beta \\
\hline 1 (Constant) & .049 & .328 & \\
\hline $\begin{array}{l}\text { Mutu } \\
\text { Tabungan }\end{array}$ & .359 & .082 & .327 \\
\hline
\end{tabular}

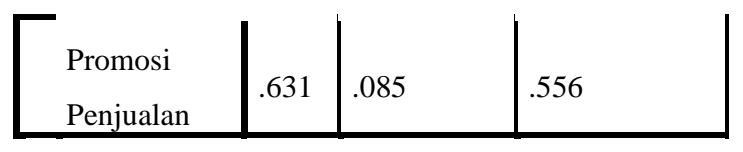

a. Dependent Variable: Minat Menabung Sumber : Data olahan SPSS V23 (2020)

Dari hasil tersebut apabila ditulis dalam bentuk Unstandardized dari persamaan regresinya adalah sebagai berikut: $\mathrm{Y}=0,049+0,359 \mathrm{X} 1+0,631 \mathrm{X} 2+\mathrm{e}$

Model persamaan persamaan regresi Unstandardized Coefficients, nilai koefisiennya sebagai berikut:

a) Konstanta 0,049 berarti bahwa Minat menabung Nasabah akan tetap konstan sebesar 0,049 jika tidak ada pengaruh dari variable Mutu tabungan (X1), dan Promosi penjualan (X2),

b) Koefisien regresi X1 sebesar 0,359 memberikan arti bahwa Mutu tabungan (X1) berpengaruh positif terhadap Minat menabung Nasabah (Y). Hal ini menunjukkan bahwa dengan adanya Mutu tabungan, maka terjadi peningkataan pada Minat menabung Nasabah begitupun sebaliknya jika Mutu tabungan tidak dilakukan.

c) Koefisien regresi X2 sebesar 0,631 memberikan arti bahwa Promosi penjualan (X2) berpengaruh positif terhadap Minat menabung Nasabah (Y). Hal ini menunjukkan bahwa dengan adanya Promosi penjualan maka akan terjadi peningkatan Minat menabung Nasabah begitupun sebaliknya jika Promosi penjualan tidak dilakukan.

\section{Hasil Pengujian Hipotesis}

\section{a. Pengujian Parsial $(\mathbf{U j i}-\mathbf{t})$}

Uji $\mathrm{t}$ dilakukan untuk mengetahui pengaruh masing-masing atau secara parsial variabel independen (Mutu tabungan Dan Promosi penjualan) 
terhadap variabel dependen (Minat menabung Nasabah). Sementara itu secara parsial pengaruh dari kedua variabel independen tersebut terhadap Minat menabung Nasabah ditunjukkan pada tabel berikut:

Tabel 4 Hasil Perhitungan uji-t Coefficients $^{\mathrm{a}}$

\begin{tabular}{|ll|l|l|}
\hline \multicolumn{2}{|l|}{ Model } & $\mathrm{t}$ & Sig. \\
\hline $1 \quad$ (Constant) & .148 & .882 \\
& Mutu Tabungan & 4.375 & .000 \\
& Promosi Penjualan & 7.447 & .000 \\
\hline
\end{tabular}

a. Dependent Variable: Minat Menabung Sumber : Data olahan SPSS V23 (2020)

Pengujian dengan membandingkan nilai $t_{\text {hitung }}>t_{\text {tabel }}$ sebesar 1.985 nilai ini diperoleh dari MsExcel $=\operatorname{TINV}(5 \%, 97)$ dan nilai signifikan < 0,05 maka hipotesis diterima. Berdasarkan pertimbangan Tabel 4 diperoleh kesimpulan sebagai berikut:

1) Pengaruh Mutu tabungan terhadap Minat menabung Nasabah Pernyataan Hipotesis Pertama $\mathrm{H}_{\mathrm{a}}$ : Mutu tabungan berpengaruh positif dan signifikan terhadap Minat menabung Nasabah.

$\mathrm{H}_{0}$ : Mutu tabungan tidak berpengaruh positif dan signifikan terhadap Minat menabung Nasabah.

Berdasarkan Tabel 4 untuk Mutu tabungan (X1) dengan Nilai $t_{\text {hitung }}(4.375)>$ $\mathrm{t}_{\text {tabel }}(1.985)$ serta nilai signifikannya $(0,000)$ $<(0,05)$ sehingga terbukti bahwa variabel Mutu tabungan berpengaruh positif dan signifikan terhadap Minat menabung Nasabah, maka pada tingkat kekeliruan 5\% dinyatakan untuk hipotesis pertama bahwa
Ha diterima dan $\mathrm{H} 0$ ditolak.

2) Pengaruh Promosi penjualan terhadap Minat menabung Nasabah

Pernyataan Hipotesis Kedua

Ha: $\begin{array}{lr}\text { Promosi penjualan } \\ \text { berpengaruh positif dan } \\ \text { signifikan terhadap Minat } \\ \text { menabung Nasabah. } \\ \text { H0: } & \text { Promosi penjualan tidak } \\ & \text { berpengaruh positif dan } \\ & \text { signifikan terhadap Minat } \\ & \text { menabung Nasabah. }\end{array}$

Berdasarkan Tabel 5.11 untuk Promosi penjualan (X2) dengan Nilai $t_{\text {hitung }}(7.447)>t_{\text {tabel }}(1.985)$ serta nilai signifikannya $(0,000)<(0,05)$ terbukti bahwa variabel Promosi penjualan berpengaruh positif dan signifikan terhadap Minat menabung Nasabah, maka pada tingkat kekeliruan 5\% dinyatakan untuk hipotesis kedua bahwa Ha diterima dan $\mathrm{HO}$ ditolak.

\section{a. Mutu tabungan berpengaruh positif dan signifikan terhadap Minat menabung Nasabah}

Hasil penelitian ini menunjukkan bahwa Mutu tabungan berpengaruh positif terhadap Minat menabung Nasabah. Mutu tabungan (X1) dengan Nilai $t_{\text {hitung }}(4.375)>t_{\text {tabel }}(1.985)$ serta nilai signifikannya $(0,000)<(0,05)$ sehingga terbukti bahwa variabel Mutu tabungan berpengaruh positif dan signifikan terhadap Minat menabung Nasabah, maka pada tingkat kekeliruan $5 \%$ dinyatakan untuk hipotesis pertama bahwa Ha diterima dan $\mathrm{H} 0$ ditolak.

Hal ini dapat dibuktikan dari tanggapan responden terhadap variabel Mutu tabungan Nasabah mayoritas reponden menjawab setuju dengan total mean 3.97. Dari tanggapan responden tentang Mutu tabungan Nasabah lebih memilih setuju pada pernyataan ketiga 
dengan pembahasan indikator "Reliabilitas" yang berarti nasahah menganggap fitur tabungan Bank SULSELBAR tidak pernah mengalami kegagalan dalam hal pengoperasian. Hal ini sama halnya dari tanggapan responden terhadap variabel Minat menabung Nasabah mayoritas reponden menjawab setuju dengan total mean 4.00. Dari tanggapan responden tentang Minat menabung Nasabah lebih memilih setuju pada pernyataan keempat dengan pembahasan indikator "Faktor motif social" yang berarti minat nasabah menabung pada Bank SULSELBAR karena fitur tabungan Bank SULSELBAR sedang populer. Hal ini berarti dengan meningkatnya Mutu tabungan yang ditinjau dari segi indikator "Reliabilitas" maka dapat meningkatkan Minat menabung yang ditinjau dari segi "Faktor motif social".

Hasil penelitian ini juga sejalan dengan pendapat Anshori (2014) adalah simpanan yang penarikannya hanya dapat dilakukan menurut syarat tertentu yang disepakati, tetapi tidak dapat ditarik dengan cek, bilyet giro dan atau alat lainnya yang dipersamakan dengan itu. Nasabah jika hendak mengambil simpanannya dapat datang langsung ke bank dengan membawa buku tabungan, slip penarikan, atau melalui fasilitas ATM. Berdasarkan penjelasan tersebut, maka mutu tabungan adalah keunggulan pada simpanan yang bertujuan untuk mempermudah nasabah dalam melakukan transaksi dengan syarat syarat yang telah disepakati.

Hubungan Mutu Tabungan terhadap Minat Menabung menurut Suryani (2017) menyatakan bahwa pemahaman terhadap produk dan jasa perbankan serta karakteristiknya sangat penting bagi pemasar agar dapat menawarkan produk tersebut secara tepat. Produk adalah pemahaman subyektif produsen atas sesuatu yang bisa ditawarkan sebagai usaha untuk mencapai tujuan organisasai melalui pemenuhan kebutuhan dan keinginann konsumen, sesuai dengan kompetensi dan kapasitas organisasi serta daya beli pasar, selain itu produk dapat pula di definisikan sebagai persepsi konsumen yang di jabarkan oleh produsen melalui hasil produksi atau operasinya. Apabila produsen dapat menjelasankan mutu produk kepada konsumen dengan didukung berbagai keunggulan produk tersebut, maka dapat meningkatkan minat menabung nasabah sehingga hal tersebut dapat menjadi penanda bahwa nasabah telah menikmati keunggulan dari produk tersebut.

Hal ini sejalan dengan penelitian yang dilakukan oleh Syaribulan (2018) dalam hasil penelitiannya menemukan bahwa Mutu tabungan berpengaruh positif dan signifikan terhadap Minat menabung. Artinya, semakin tinggi Mutu tabungan semakin tinggi Minat menabung.

\section{b. Promosi penjualan berpengaruh positif dan signifikan terhadap Minat menabung Nasabah}

Hasil penelitian menunjukkan bahwa Promosi penjualan berpengaruh positif dan signifikan terhadap Minat menabung Nasabah. Promosi penjualan (X2) dengan Nilai $t_{\text {hitung }}(7.447)>t_{\text {tabel }}$ (1.985) serta nilai signifikannya $(0,000)$ $<(0,05)$ terbukti bahwa variabel Promosi penjualan berpengaruh positif dan signifikan terhadap Minat menabung Nasabah, maka pada tingkat kekeliruan 5\% dinyatakan untuk hipotesis kedua bahwa Ha diterima dan $\mathrm{HO}$ ditolak.

Hal ini dapat dibuktikan dari tanggapan responden terhadap variabel Promosi penjualan mayoritas reponden menjawab setuju dengan total mean 4.00. Dari tanggapan responden tentang Promosi penjualan lebih memilih setuju 
artinya responden setuju pada pernyataan pertama dengan pembahasan indikator "Personal Selling" yang berarti kebanyakan Nasabah menganggap Kamampuan pegawai dalam mempromosikan fitur tabungan Bank SULSELBAR membuat nasabah lebih mudah mengerti. Hal ini sama halnya dari tanggapan responden terhadap variabel Minat menabung Nasabah mayoritas reponden menjawab setuju dengan total mean 4.00. Dari tanggapan responden tentang Minat menabung Nasabah lebih memilih setuju pada pernyataan keempat dengan pembahasan indikator "Faktor motif social" yang berarti minat nasabah menabung pada Bank SULSELBAR karena fitur tabungan Bank SULSELBAR sedang populer. Hal ini berarti dengan meningkatnya promosi penjualan yang ditinjau dari segi indikator "Personal Selling" maka dapat meningkatkan Minat menabung yang ditinjau dari segi "Faktor motif social".

Hasil penelitian ini sesuai dengan pendapat menurut Tjiptono (2014: 219) Promosi dapat didefinisikan sebagai suatu bentuk komunikasi pemasaran, komunikasi pemasaran adalah aktivutas pemasaran yang berusaha menyebarkan informasi, mempengaruhi, membujuk maupun mengingatkan pasar sasaran atas perusahaan dan produknya agar bersedia menerima, membeli, dan loyal pada produk yang ditawarkan perusahaan yang bersangkutan.

Hubungan Promosi Penjualan terhadap Minat Menabung menurut Daniel dan Anas (2017:89) menyatakan bahwa Promosi merupakan salah satu cara bank untuk menarik dan mempertahankan masyarakat agar tetap menabung pada bank tersebut Namun kegiatan promosi yang dilakukan bank juga bisa mengurangi minat masyarakat untuk menabung pada bank tersebut apabila dilakukan dengan tujuan dan penyampaian yang tidak tepat bahkan berlebihan. Oleh karena itu, bank harus dapat memanfaatkan dengan baik dan benar media promosi seperti iklan pada media cetak atau elektronik, promosi langsung dan lain sebagainya. Dalam hal ini bank harus mengetahui media promosi yang paling mudah dimengerti dan sering dijumpai oleh masyarakat.

Hal ini sejalan dengan penelitian yang dilakukan oleh Syaribulan (2018) dalam hasil penelitiannya menemukan bahwa Promosi penjualan berpengaruh signfikan terhadap Minat menabung. Artinya, semakin tinggi Promosi penjualan semakin tinggi Minat menabung.

\section{c. Mutu tabungan dan Promosi penjualan berpengaruh positif dan signifikan secara simultan terhadap Minat menabung Nasabah}

Hasil penelitian menunjukkan bahwa Mutu tabungan dan Promosi penjualan berpengaruh positif dan signifikan secara simultan terhadap Minat menabung Nasabah. Berdasarkan pengujian simultan (uji - F) menunjukkan bahwa nilai $\mathrm{f}_{\text {hitung }}$ sebesar $74.517>\mathrm{f}_{\text {tabel }}$ sebesar 3.090 (nilai ini diperolaeh dari MsExcel $=F I N V(5 \%, 2,93)$ lalu enter $)$ dengan nilai signifikasi (sig) sebesar $(0.000)<(0,05)$ maka pada tingkat kekeliruan 5\% dapat dikatakan hipotesis ketiga diterima yang berarti Mutu tabungan dan Promosi penjualan berpengaruh positif dan signifikan secara simultan terhadap Minat menabung Nasabah.

Hal ini dapat dibuktikan dari tanggapan responden terhadap variabel Mutu tabungan Nasabah mayoritas reponden menjawab setuju dengan total mean 3.97. Dari tanggapan responden tentang Mutu tabungan Nasabah lebih 
memilih setuju pada pernyataan ketiga dengan pembahasan indikator "Reliabilitas" yang berarti nasahah menganggap fitur tabungan Bank SULSELBAR tidak pernah mengalami kegagalan dalam hal pengoperasian. Serta, dari tanggapan responden terhadap variabel Promosi penjualan mayoritas reponden menjawab setuju dengan total mean 4.00. Dari tanggapan responden tentang Promosi penjualan lebih memilih setuju artinya responden setuju pada pernyataan pertama dengan pembahasan indikator "Personal Selling" yang berarti kebanyakan Nasabah menganggap Kamampuan pegawai dalam mempromosikan fitur tabungan Bank SULSELBAR membuat nasabah lebih mudah mengerti. Hal ini sama halnya dari tanggapan responden terhadap variabel Minat menabung Nasabah mayoritas reponden menjawab setuju dengan total mean 4.00. Dari tanggapan responden tentang Minat menabung Nasabah lebih memilih setuju pada pernyataan keempat dengan pembahasan indikator "Faktor motif social" yang berarti minat nasabah menabung pada Bank SULSELBAR karena fitur tabungan Bank SULSELBAR sedang populer. Hal ini berarti dengan meningkatnya Mutu tabungan yang ditinjau dari segi indikator "Reliabilitas" dan meningkatnya Promosi penjualan yang ditinjau dari segi indikator "Personal Selling" maka dapat meningkatkan Minat menabung yang ditinjau dari segi "Faktor motif social".

Hasil penelitian ini sesuai dengan pendapat menurut Suryani (2017) menyatakan bahwa pemahaman terhadap produk dan jasa perbankan serta karakteristiknya sangat penting bagi pemasar agar dapat menawarkan produk tersebut secara tepat serta menurut Daniel dan Anas (2017:89) menyatakan bahwa Promosi merupakan salah satu cara bank untuk menarik dan mempertahankan masyarakat agar tetap menabung pada bank tersebut. Swastha dan Irawan (2013: 339) menyatakan bahwa "Minat beli berhubungan dengan perasaan dan emosi, bila seseorang merasa senang dan puas dalam membeli barang atau jasa maka hal itu akan memperkuat minat beli, ketidakpuasan biasanya menghilangkan minat. Minat beli yang ada dalam diri konsumen merupakan fenomena yang sangat penting dalam kegiatan pemasaran, minat beli merupakan suatu perilaku konsumen yang melandaskan suatu keputusan pembelian yang hendak dilakukan".

Hasil penelitian ini juga sejalan dengan penelitian yang dilakukan oleh Syaribulan (2018) membuktikan dalam penelitianya bahwa mutu tabungan dan promosi penjualan berpengaruh positif dan signifikan secara simultan terhadap minat menabung. Sehingga dapat dibuktikan bahwa penerapan mutu tabungan dan promosi yang menjadi salah satu faktor penentu minat menabung.

\section{E. KESIMPULAN}

\section{Kesimpulan}

Penelitian ini bertujuan untuk menguji dan menganalisis pengaruh Mutu tabungan dan Promosi penjualan terhadap Minat menabung Nasabah pada PT. Bank SULSELBAR Makassar. Dari rumusan masalah penelitian yang diajukan, maka analisis data yang telah dilakukan dapat ditarikbeberapa kesimpulan, yaitu:

a. Analisis secara parsial (uji-t), ternyata hasil penelitian membuktikan bahwa variabel independen, yaitu Mutu tabungan (X1) berpengaruh 
positif dan signifikan secara parsial terhadap Minat menabung Nasabah (Y) pada PT. Bank SULSELBAR Makassar, maka dinyatakan hipotesis pertama diterima,

b. Analisis secara parsial (uji-t), ternyata hasil penelitian membuktikan bahwa variabel independen, yaitu Promosi penjualan (X2), berpengaruh positif dan signifikan secara parsial terhadap Minat menabung Nasabah (Y) pada PT. Bank SULSELBAR Makassar, maka dinyatakan hipotesis kedua diterima,

c. Analisis secara simultan (ujiF), ternyata hasil penelitian membuktikan bahwa variabel independen, yaitu Mutu tabungan (X1) dan Promosi penjualan (X2), berpengaruh positif dan signifikan secara simultan terhadap Minat menabung Nasabah (Y) pada PT. Bank SULSELBAR Makassar, maka dinyatakan

\section{DAFTAR PUSTAKA}

Akhmad Darmawan Dkk. (2019). Analisis Faktor-Faktor Yang Mempengaruhi Minat Nasabah Menabung Di Bank Jateng Syariah. Jurnal Ekonomi Dan Bisnis. Jurnal Fokus Bisnis, Vol.18, No.01, hal 43-52.

Anshori, Abdul Ghofur 2014. Perbankan Syariah di Indonesia. Yogyakarta : Gadjah. Mada University Press.

Assauri, Sofjan. 2011. "Strategic Management, Sustainable hipotesis ketiga diterima.

\section{Saran}

a. Bagi Bank SULSELBAR, sebaiknya perusahaan harus mampu mempertahankan para nasabahnya dengan meningkatkan pendekatan yang bertujuan untuk mempengaruhi para nasabah dalam Minat menabung Nasabah. Dalam mengetahui Minat menabung nasabah dapat diketahui melalui Mutu tabungan yang memiliki Kinerja, Fitur, Reliabilitas, Kesesuaian dengan spesifikasi, Daya tahan, Layanan, Estetika, dan Kualitas yang dipersepsikan. Dalam melihat Promosi penjualan dapat ditekankan dalam hal Personal Selling, Advertising, Sales Promotion, dan Public Relation.

b. Bagi pihak lain, sebaiknya dapat melihat bagaimana Minat menabung Nasabah yang dapat dilihat dari segi Faktor dorongan dari dalam, Faktor motif social, dan Faktor emosional atau perasaan.

Competitive. Advantage". Indonesia, Jakarta.

Basuki, Agus Tri Dan Prawoto, Nano. (2016). Analisis Regresi Dalam Penelitian. Ekonomi \& Bisnis. Jakarta: Raja Grafindo.

Budisantoso,Totok Dan Sigit Triandaru.2011.Bank Dan Lembaga Keuangan. Lainnya.Edisi Dua.Jakarta:Salemba Empat.

Dani Dan Harry. (2016). Analisis Pengaruh Atribut Tabungan, Mutu Tabungan Dan Promosi Penjualan Terhadap Citra Perusahaan Dalam 
Meningkatkan Minat Menabung Nasabah Tabungan (Studi Kasus Pada Bank Jateng Cabang Kordinator Semarang). Jurnal Ekonomi Dan Bisnis

Daniel dan Anas. 2017. Pengaruh Media Promosi Perbankan Syariah Terhadap Minat Menabung Masyarakat di Bank Syariah. Jurnal Ekonomi Syariah Vol 5 No 1, hal 89.

Dedy Dan Agus. (2018). Pengaruh Kualitas Produk Tabungan Dan Kualitas Layanan Terhadap Minat Menabung Kembali Di Bank X ( Studi Kasus Pt Bank X Cabang Bintaro ). Jurnal Ekonomi Dan Bisnis

Frendy.2011: Metode Penelitian Untuk Bisnis, Salemba Empat, Jakarta.

Gea, Boy Ramadhan (2017) Faktor-Faktor Yang Mempengaruhi Referensi Nasabah Terhadap Produk Pembiayaan Multijasa Pada Pt.Bprs Al-Wasliyah Kota Medan. Skripsi Thesis, Universitas Islam Negeri Sumatera Utara.

Ghozali, Imam. 2011. "Aplikasi Analisis Multivariate Dengan Program Spss". Semarang: Badan Penerbit Universitas Diponegoro.

Handoko. 2015. Manajemen, Edisi 2, Bpfe, Yogyakarta.

Kotler, Philip \& Gerry Armstrong, (2014): Principle Of Marketing, 15th Edition. New Jersey: Pearson Pretice

Kotler, Philip And Kevin Lane Keller, (2016): Marketing Management, 15th. Edition New Jersey: Pearson Pretice Hall, Inc.

Latumaerissa (2011), Bank Dan Lembaga Keuangan Lain, Jakarta: Salemba. Empat.
Mawardi. (2018). Pengaruh Promosi Tabungan Bank Sumsel Babel Syariah Terhadap Minat Menabung Masyarakat Kota Palembang. Jurnal Ekonomi dan Bisnis Islam. Vol. 4, No. 1, Hal. 43-52.

Rezeki dan Sukmadilaga. (2018). FaktorFaktor Yang Mempengaruhi Minat Nasabah Pada Perbankan Syariah. Jurnal Ekonomi dan Bisnis Islam. Volume VIII, Nomor 1, Halaman 4450 .

Russel, R. S. Dan Taylor, B.W. (2011). Operations Management: Along The Supplychain, 7 Thed. Nj: Wiley.

Sugiyono. (2017). Metode Penelitian Kuantitatif, Kualitatif, Dan R\&D. Bandung : Alfabeta,.

Suryabrata, Sumadi, 2011. Psikologi Pendidikan, Jakarta: Pt. Rajagrafindo Persada

Suryani, Tatik. 2017. Perilaku Konsumen di Era Internet. Yogyakarta: Graha. Ilmu.

Swastha dan Irawan. 2013. Manajemen Pemasaran Modern, Liberty,. Yogyakarta.

Syaribulan. (2018). Bauran Pemasaran Dan Pengaruhnya Terhadap Minat Nasabah Untuk Menabung Di Tabungan Tampan, Bank Sulselbar. Jurnal Manajemen, Ide, Inspirasi (MINDS). Vol.5, No. 1, hal 39-52.

Terence. 2014. Komunikasi Pemasaran Terpadu Dalam Periklanan Dan. Promosi. Jakarta: Salemba Empat.

Tjiptono. 2014. Pemasaran Jasa. Andi : Yogyakarta.

Trotoar.id (2020). Awal Tahun 2020, Bank Sulselbar Raih Penghargaan. 
ISSN 2656-2790 (online)

https://trotoar.id/2020/01/03/awaltahun-2020-bank-sulselbar-raih- penghargaan/. Diakses pada Oktober 2020. 